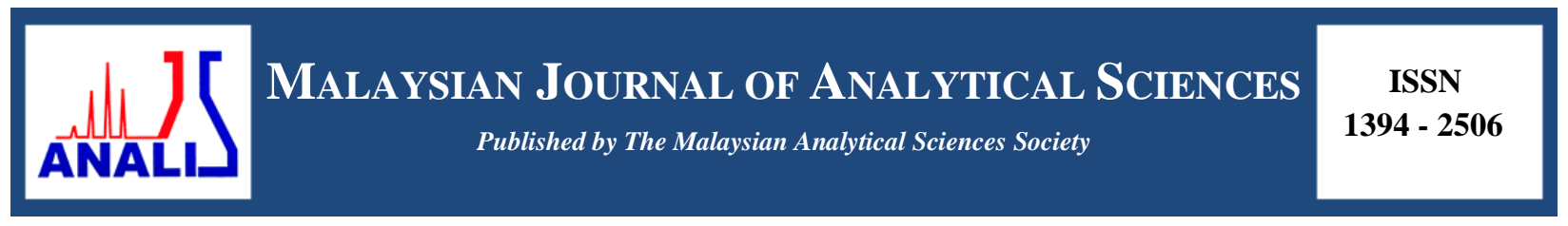

\title{
MOLECULAR WEIGHT CUT-OFF DETERMINATION OF PRESSURE FILTRATION MEMBRANES VIA COLORIMETRIC DETECTION METHOD
}

\author{
(Penentuan Berat Sekatan Molekul Bagi Membran Penurasan TekananMelalui Kaedah \\ Pengesanan Kolorimetri)
}

\author{
Izzati Izni Yusoff, Rosiah Rohani*, Abdul Wahab Mohammad \\ Department of Chemical and Process Engineering, \\ Faculty of Engineering and Built Environment, \\ Universiti Kebangsaan Malaysia, 43600 UKM Bangi, Selangor, Malaysia \\ *Corresponding author: rosiah@ukm.edu.my
}

Received: 21 October 2015; Accepted: 14 June 2016

\begin{abstract}
Molecular weight cut-off (MWCO) of commercial and in-house fabricated membranes is obtained at $90 \%$ rejection of various types of solutes with different molecular weights (MWs). PEG quantification methods have been favorably employed to determine membranes' MWCO. Most of the quantification methods utilizing high-end equipment using high performance liquid chromatography (HPLC) and low-end colorimetric method. HPLC method requires an established chromatographic technique using specific diluents, columns and detectors while the most referred colorimetric method requires a few processing steps with concentration up to $7.5 \mathrm{ppm}$ by using UV spectrophotometer. In this work, a newly modified colorimetric method was established to conduct a simple measurement for a membrane's MWCO. The newly modified method has an excellent linearity for the calibration curves which $\mathrm{R}^{2}$ values are closed to 1 with concentration of up to $150 \mathrm{ppm}$. A MWCO determination test conducted using different commercial membranes for confirming this newly modified method found that similar MWCO values were obtained as given by the membrane' manufacturers. In conclusion, this newly modified method is simpler than the formerly used colorimetric method, reliable and applicable for determining the MWCO of membranes ranging from UF to NF at a higher range of PEG concentrations (>150 ppm).
\end{abstract}

Keywords: molecular weight cut-off, polyethylene glycol, spectrophotometric, colorimetric, membrane

\begin{abstract}
Abstrak
Berat sekatan molekul (MWCO) bagi membran komersial dan yang dihasilkan sendiri diperolehi pada $90 \%$ penolakan pelbagai jenis bahan larut dengan berat molekul yang berbeza (MWs). Kaedah kuantifikasi menggunakan PEG adalah yang paling digemari digunakan bagi menentukan MWCO daripada membran yang di sintesis. Kebanyakan kaedah menggunakan peralatan atasan seperti kromatografi cecair berprestasi tinggi (HPLC) dan kaedah bawahan seperti kaedah kolorimetri. Kaedah HPLC memerlukan teknik kromatografi yang tertubuh menggunakan bahan pencair, tiang dan pengesan tertentu manakala kaedah kolorimetri memerlukan beberapa langkah pemprosesan dengan kepekatan hanya dalam julat sehingga 7.5 ppm menggunakan spektrofotometer UV. Oleh yang demikian dalam kajian ini, satu kaedah kolorimetri baru yang diubahsuai telah ditubuhkan untuk mengukur MWCO membran. Kaedah ini mempunyai kelinearan yang sangat baik, di mana nilai $\mathrm{R}^{2}$ menghampiri 1 dengan kepekatan sehingga $150 \mathrm{ppm}$. Ujian penentuan MWCO dijalankan menggunakan beberapa membran komersial yang berbeza untuk mengesahkan kaedah baru diubahsuai ini didapati bahawa nilai MWCO yang sama telah diperolehi bagi membran, seperti yang diberikan oleh pengeluar membran. Kesimpulannya, kaedah yang baru diubahsuai ini adalah lebih mudah daripada kaedah kalorimetri yang dahulunya digunakan, boleh dipercayai dan diguna pakai bagi menentukan MWCO daripada membran NF sehingga membran UF malah pada julat kepekatan PEG yang lebih tinggi.
\end{abstract}




\section{Izzati Izni et al: MOLECULAR WEIGHT CUT-OFF DETERMINATION OF PRESSURE FILTRATION MEMBRANES VIA COLORIMETRIC DETECTION METHOD}

Kata kunci: berat sekatan molekul, polietilena glikol, spektrofotometer, kolorimetri, membran

\section{Introduction}

Membrane-based technologies are the leading technology for all kinds of separation techniques due to its intrinsic characteristics such as operational simplicity, environmental impact, high selectivity and permeability in transport of specific components [1]. A membrane is an interphase between two adjacent phases acting as a selective barrier, regulating the transport of substances between the two compartments for separating feed species such as mixture of liquid, gas and colloidal particle [2, 3]. Membranes with good resistant and selectivity are necessary to ensure efficient separation process and very important for the industrial sector to obtain high purity products. Selectivity is dependent on the pore size of the membranes [4]. Furthermore, one of the major factor in obtaining an effective separation is by determining relative size of solute molecule to pass through the membrane pores [5]. Thus, the pore sizes of the membrane and its distribution play a crucial role in determining the efficiency of filtration $[6,7]$.

Membrane pore sizes could be determined by several analytical methods. Solute rejection method, bubble point method, soluble probe method, liquid replacement and visual observation techniques (e.g., atomic force microscopy and scanning electron microscopy) are the methods commonly employed to measure the pore sizes of membranes [8 - 10]. Each of these methods has its own advantages and limitations. Some of the techniques outlined might not be useful in the determination of pore size of membranes in term of their molecular weight cut-off (MWCO) since they cannot predict the membranes' sieving effects based on the removal of particles and solutes through the membranes under actual operating conditions and transport mechanism [10, 11].

Among the outlined methods, the solute rejection method is an effective technique to investigate the separation characteristics of various solutes by membranes because it measures solute rejection using actual filtration experiments with non-ionic solutes of a known molecular weight (MW) such as polyethylene glycol (PEG), oligostyrenes, alkanes and dextrans[10]. A membrane's MWCO is a representation of membrane selectivity for solute molecules of different MW, where the MW value is obtained from the solute molecule that gives a $90 \%$ rejection when a range of different MW solutes are filtered in the targeted solvent $[12,13]$. PEGs have been widely used for the determination of the nominal MWCO because of their colloidal properties, which gives low-fouling levels [11]. There are various detection methods for PEG but most of the methods utilizing high-end equipment such as high performance liquid chromatography (HPLC) and low-end colorimetric method. HPLC method requires an established chromatographic technique using specific diluents, columns and detectors while colorimetric method requires a number of processing steps to dilute PEG based on the formation of a complex with barium chloride and iodine solution until a very low concentration of up to $7.5 \mathrm{ppm}$ using UV spectrophotometer [14]. Since most reliable PEG detection techniques require the use of sophisticated instruments (which some instrument may not be available in many laboratories) and apply complex protocols, the colorimetric detection method have attracted considerable attentions in PEG detection applications with regard to their simplicity and versatility [15].

MWCO determination by colorimetric method was first used by [16] and has been extensively used thereafter by many research groups worldwide for quantifying the MWCO of their fabricated membranes [3, 5, 17-19]. However, there is no work ever reported to date, on the verification of the method with any types of commercial membranes of known MWCO to confirm its accuracy. Furthermore, the MWCO of the reported synthesized membranes were only in the ultrafiltration (UF) ranges. For instance, [16] reported the MWCO of the synthesized membrane from cellulose acetate butyrate was around $15,000 \mathrm{~g} / \mathrm{mol}$ upon using PEGs in range of 1,000 to $20,000 \mathrm{~g} / \mathrm{mol}$ to determine the MWCO value. In different occasions, [3] and [17] have used PEGs with MW of up to 35,000 and $65,000 \mathrm{~g} / \mathrm{mol}$, respectively, for the MWCO determination and the reported MWCO was also in UF ranges. So far, the method has never been reported for determining the MWCO of nanofiltration (NF) range membranes other than UF only. NF membrane is one type of pressure filtration membrane, situated between reverse osmosis (RO) and UF. NF typically represents filtration and rejection of solutes with sizes in the region of $200-2,000 \mathrm{~g} / \mathrm{mol}$ [20] while UF represents solutes greater than $2,000 \mathrm{~g} / \mathrm{mol}$. Thus, this colorimetric method for PEG detection in the NF to UF membrane MWCO application has become the basis to be focused in this study. 
Next, one of the identified drawback of this colorimetric method for MWCO determination is that it uses very low solute concentrations [16]. This is because at high concentration of PEG, the solute solution tends to precipitate. Thus, the reaction for this method is dependent on the concentration of the solution used [21]. However, low concentration of solute rejection may affect the membrane solute retention, in which consequently caused inaccurate MWCO reading. The concentration influenced the dipole moment interaction, which in turn affected the solute rejection [20]. Therefore, high concentration of feed solution is required to be used when performing the pressured membrane filtration in order to obtain a more accurate permeate concentration prediction [22]. Therefore in this study, a simple yet sensitive and detectable PEG of various MW ranges $(600-20,000 \mathrm{~g} / \mathrm{mol})$ at different concentration ranges from low $(0 \mathrm{ppm})$ and high $(150 \mathrm{ppm})$ was established for a simple and reliable MWCO determination method in comparison to the previous method reported by [16]. This newly modified method is further tested using various commercial membranes of NF and UF for method verification to confirm the feasibility of the modified colorimetric method for determining MWCO of the membranes.

\section{Materials}

\section{Materials and Methods}

Barium chloride, hydrochloric acid, potassium iodide and iodine were supplied by Friendemann Schmidt from Chemolab Supplies. PEG with nominal MW (g/mol) of 600 (PEG600), 1,000 (PEG1000), 3,000 (PEG3000), 6,000 (PEG6000), 10,000 (PEG10000) and 20,000 (PEG20000) were from Sigma Aldrich supplied by Chemolab Supplies. Table 1 showed the properties of the PEGs involved. All chemicals were used as received.

Table 1. Various PEG properties differentiated by their MW

\begin{tabular}{llcc}
\hline PEG MW & Appearance & $\mathbf{M}_{\mathbf{n}}(\mathbf{g} / \mathbf{m o l})$ & Hydroxyl Value \\
\hline PEG600 & Clear viscous colourless liquid & $590-610$ & $176-200$ \\
PEG1000 & White waxy solid & $950-1,050$ & $105-120$ \\
PEG3000 & White flakes & $2,700-3,300$ & $34-42$ \\
PEG6000 & White flakes & $5,500-6,500$ & $16-20$ \\
PEG10000 & White flakes & $9,000-12,500$ & $9-12$ \\
PEG20000 & White flakes & $16,000-28,000$ & $4-7$ \\
\hline
\end{tabular}

A range of commercial membranes with different nominal MWCO from 200 to 20,000 $\mathrm{g} / \mathrm{mol}$ (produced by different manufacturers) that were used in this work are tabulated in Table 2 below.

Table 2. List of commercial membranes with their nominal MWCO and manufacturer

\begin{tabular}{lcl}
\hline Membranes & $\begin{array}{c}\text { Nominal MWCO } \\
\text { Given by Manufacturer }(\mathbf{g} / \text { mol) }\end{array}$ & Manufacturer \\
\hline NF $^{\mathrm{TM}}$ & $200-300$ & Dow Filmtec $^{\mathrm{TM}}$ \\
$\mathrm{NF} 2$ & $200-400$ & Amfor Inc. \\
$\mathrm{NF} 270$ & 400 & Dow Filmtec \\
$\mathrm{PES} 3$ & 3,000 & Amfor Inc. \\
$\mathrm{TF}(\mathrm{GM})$ & 4,000 & GE Osmonics \\
PES10 & 10,000 & Amfor Inc. \\
PS20 & 20,000 & Amfor Inc. \\
\hline
\end{tabular}




\section{Reagents and PEG preparation}

There were two types of reagents used for the determination of PEG, namely iodine solution (Reagent 1) and barium chloride solution (Reagent 2). Reagent 1 was prepared by dissolving $1.27 \mathrm{~g}$ iodine crystal in $100 \mathrm{~mL}$ of $2 \%$ $(\mathrm{w} / \mathrm{v})$ solution. It was further diluted for 10 times prior to use. Reagent 2 was prepared by dissolving $5 \mathrm{~g}$ of barium chloride in $100 \mathrm{~mL}$ of $1 \mathrm{M}$ hydrochloride acid to form a 5\% (w/v) solution [16]. $150 \mathrm{ppm}$ PEG solutions (PEG600, PEG1000, PEG3000, PEG6000, PEG10000 and PEG20000) were prepared by dissolving $0.15 \mathrm{~g}$ of PEG in $1 \mathrm{~L}$ ultrapure water (Arium ${ }^{\circledR}$ Pro, Sartorius Malaysia Sdn Bhd, Malaysia). The solution was then being sonicated by using Analog Ultrasonic Cleaner (WUC-A03H, Daihan Scientific).

To plot PEGs standard curve, a series of concentration were prepared in range 2.5 - $7.5 \mathrm{ppm}$ for Sabde et al. method while $10-150 \mathrm{ppm}$ for the newly modified method (proposed in this work). Blank for both methods were prepared by using ultrapure water and were also added with reagent 1 and 2 as samples while blank used for spectrophotometer (Genesys 10UV, Thermo Electron Corporation, USA) was ultrapure water without addition of any reagents.

\section{Newly modified PEG method}

In initial MWCO determination method using PEG, the basis of the work was based on the method reported by [16], which applies the reaction of barium and iodide with PEG to form two complexes. Whereas this newly modified method is based on the formation of a single complex between PEG and iodine only. The comparison of both methods is presented in Table 3. In the newly modified method, the concentration range is increased to $150 \mathrm{ppm}$ from $7.5 \mathrm{ppm}$ in Sabde et al. method. The PEG sample volume used for the test was only $0.3 \mathrm{~mL}$ instead of $4 \mathrm{~mL}$ as compared to the previous method. Furthermore, only 1 reagent was used in the newly modified method than the other method, which used 2 reagents. However, the reaction time to dissolve the PEG in the reagent was double to stabilize the reaction.

Table 3. Comparison between the newly modified method and the method used by Sabde et al.

\begin{tabular}{lll}
\hline Conditions & Sabde et al. Method & Newly Modified Method \\
\hline Reagent 1 (mL) & 1 & 3 \\
Reagent 2 (mL) & 1 & None \\
Samples volume (mL) & 4 & 0.3 \\
Concentration range (ppm) & $0-7.5$ & $0-150$ \\
Reaction Time (min) & 15 & 30 \\
Spectrophotometer wavelength (nm) & 535 & 535 \\
PEG MW range (g/mol) & $600-20,000$ & $600-20,000$ \\
\hline
\end{tabular}

In preparation to plot PEGs standard curve according to [16], $4 \mathrm{~mL}$ of PEG solution with different concentration were prepared in range $0-7.5 \mathrm{ppm}$. Then, $1 \mathrm{~mL}$ of each Reagent 1 and 2 were added. After 15 minutes, absorbance values were taken by using a spectrophotometer $535 \mathrm{~nm}$ against the blank reagent.

Meanwhile the standard curve plots for the newly modified method required the use of $0.3 \mathrm{~mL}$ of PEG solution in water with different concentration in the range of $0-150 \mathrm{ppm}$. Then, $3 \mathrm{~mL}$ of Reagent 1 was added. After $30 \mathrm{~min}$, absorbance values were taken by using a spectrophotometer at the same wavelength with the previous method.

\section{Methods accuracy test}

In order to test the accuracy for both methods presented and reported by Sabde et al. [16] and the newly modified method (refer Table 4), three PEG sample solutions were used to calculate their concentration by using dilution equation $\left(\mathrm{M}_{1} \mathrm{~V}_{1}=\mathrm{M}_{2} \mathrm{~V}_{2}\right)$ from the initial PEG concentration of $150 \mathrm{ppm}$. These solutions were prepared for every MW of PEGs used (from PEG600 to PEG20000). The solutions were then being tested using both methods. Table 4 
show the three solutions that were used in this test. The accuracy test is considered as successful when the final concentration values of the PEG solution calculated from dilution equation is the same or very near with the concentration values obtained from the standard curve plotted.

Table 4. Sample solutions used for methods accuracy test

\begin{tabular}{ccc}
\hline $\begin{array}{c}\text { Volume of initial } \\
\text { PEG solution }(\mathbf{m L})\end{array}$ & $\begin{array}{c}\text { Volume of ultrapure water } \\
\text { added into the solution }(\mathbf{m L})\end{array}$ & $\begin{array}{c}\text { Final concentration of PEG } \\
\text { solution calculated }(\mathbf{p p m})\end{array}$ \\
\hline 0.2 & 14.8 & 5.3 \\
0.6 & 14.4 & 16.0 \\
1.0 & 14.0 & 26.7 \\
\hline
\end{tabular}

Note: The PEG sample tested was from PEG600 to PEG20000

\section{Membrane filtration}

MWCO values of various commercial NF and UF membranes were given by the manufacturers (refer Table 2) are to be confirmed by using the newly modified method in comparison to Sabde et al. method. To determine this, solute rejections (SR) of the membranes were evaluated with various MW PEG solutions from 600 to 20,000 g/mol with concentration of $150 \mathrm{ppm}$ at 30 bar by using a dead-end filtration cell (HP4750, Sterlitech Corporation, USA) [12]. The typical representation of the feed, permeate and retentate of the filtration solution through the membrane is shown in Figure 1. The membrane SR is defined by using Eq. (1) where, $C_{f}$ and $C_{p}$ are the PEG concentrations in the feed and permeate solution, respectively. The concentration of PEG was determined based on its absorbance mode in UV-spectrophotometer at wavelength $535 \mathrm{~nm}$.

$$
\mathrm{SR}=\left(1-\frac{\mathrm{C}_{\mathrm{p}}}{\mathrm{C}_{\mathrm{f}}}\right) \times 100
$$

Water flux of membrane with an active surface area of $14.6 \mathrm{~cm}^{2}$ (which was compacted at $30 \mathrm{bar}$ for $30 \mathrm{~min}$ ) was determined by using Eq. (2) where $\mathrm{J}$ is the permeate flux $\left(\mathrm{L} . / \mathrm{m}^{2} . \mathrm{h}\right), \mathrm{V}$ is volume of permeate (L), A is effective membrane area $\left(\mathrm{m}^{2}\right)$ and $\mathrm{t}$ is operating time $(\mathrm{h})$.

$$
\mathrm{J}=\frac{\mathrm{V}}{\mathrm{Axt}}
$$

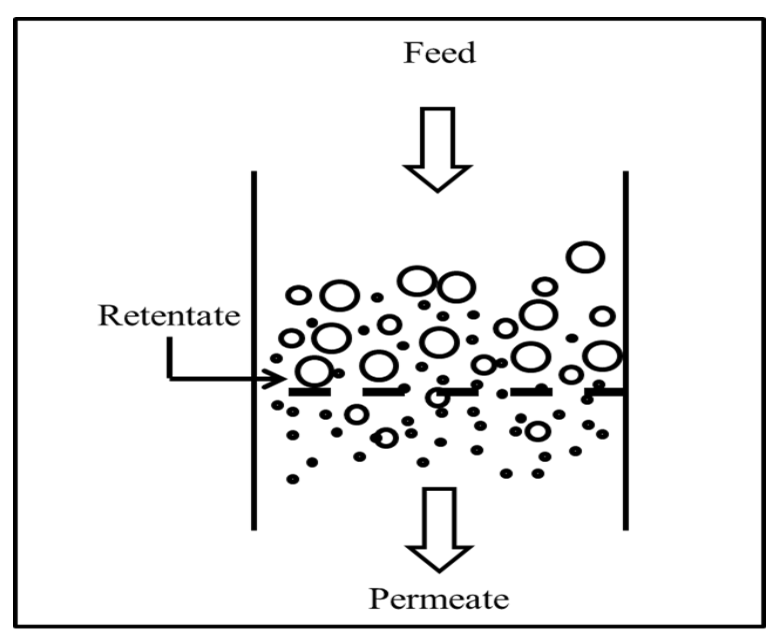

Figure 1. Schematic representation of membrane filtration system design by dead-end filtration cell 


\section{Newly modified PEG methods for MWCO determination}

\section{Results and Discussion}

The standard calibration curves plot for the newly modified method in comparison to the method used by Sabde et al. [16] are shown in Figure 2 and the summary of the linear equations from the plot is presented in Table 5. Note that Sabde et al. [16] did not present their calibration curve plot in their report, thus re-plotting is required for a fair comparison for both methods.
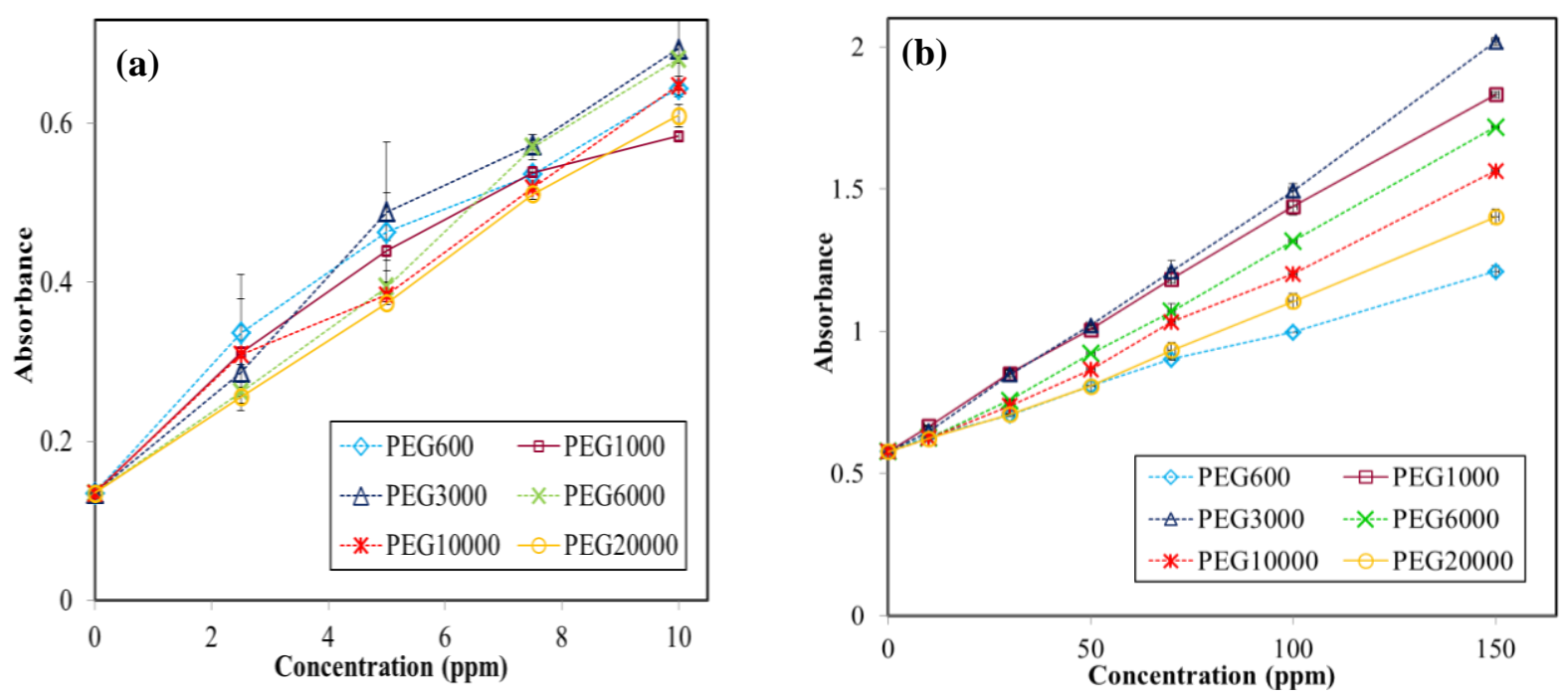

Figure 2. Standard curve of PEG for both methods with uses of PEG from MW 600 to 20,000 g/mol, a) Sabde et al. method and b) newly modified method

As shown in Figure 2 (a) and 2 (b), both methods gave a linear response to PEG at certain concentration for certain MW PEG. However, the curves for Sabde et al. method for different MW PEGs were only slightly differ to each other causes overlapping between the curves probably due to the low concentration of each of the PEGs solution used. On the other hand, the standard curves of the newly modified method showed linear curves without overlapping with one another probably because higher concentrations of solutions were used. These distinguished each curve of different PEGs MW. The curves are expected to be separated from one another for different PEGs MW since they have a different value of hydroxyl value for each of the PEGs (refer Table 1). PEG600 have the highest hydroxyl value as compared to other PEGs while PEG20000 has the lowest value. This hydroxyl value of PEG influences the absorbance reading in UV-spectrophotometer, where high MW of PEG will give low absorbance reading since their hydroxyl values are low and vice versa. The method used by Sabde et al. [16] did not show that they have this characteristic since all the standard curves plotted have overlapped to each other. This happened probably because of the reactivity of halogen group $\left(\mathrm{Cl}^{-}\right.$from barium chloride) in Sabde et al. method was lower than the iodide ion $\left(\mathrm{I}^{-}\right)$used in newly modified method. The reactivity in halogen group is in the following order ( $\mathrm{I}>\mathrm{Br}>\mathrm{Cl}>\mathrm{F}$ ) [23, 24], where $\mathrm{Cl}^{-}$is confirmed to have a low reactivity than $\mathrm{I}^{-}$in their group. Thus, it is difficult for the $\mathrm{Cl}^{-}$to completely substitute the hydroxyl group in PEG. As a result, almost the same absorbance values for PEGs were obtained even at different MW and were used to plot the standard curve at the y-axis (refer Figure 2).

Moreover, the method used by Sabde et al. [16] obtained in this work possessed linear plots for concentration from 0 to $10 \mathrm{ppm}$ only for PEG600 to PEG20000. At higher concentration (above $10 \mathrm{ppm}$ ), the complex tends to precipitate causing non-linear plots if the data is included. Although we found that $10 \mathrm{ppm}$ is the highest 
concentration to get a plot with $\mathrm{R}^{2}$ of above 0.9 than $7.5 \mathrm{ppm}$ as reported, this concentration is way too low compared to the newly modified method that can reach $150 \mathrm{ppm}$ or may be more. Initially, this colorimetric method has been successfully used by few researchers in biological fields for many years [25]. For example, it was used for detecting PEG and PEGylated molecules in biological samples like protein [26], enzyme [13] and genes [21]. Shaffer and Critchfield on year 1947 was the first to develop this most commonly cited method for quantification of PEG molecules based on the formation of insoluble complexes between PEG and heteropoly inorganic acids (phosphomolybdic and silicotungstic acid) in the presence of barium chloride. The precipitate was then collected and washed for several times prior to testing it with iodine in order to detect the PEG [25]. Perhaps, this was the main reason for the employment of barium chloride for the quantification of PEG/PEGylated molecules in biological samples and this has answered the importance of the precipitation to occur in the method reported by Shaffer and Critchfield [25]. However, in the application of membrane technology especially for MWCO determination, it was found that precipitation of PEG is an undesirable step and must be avoided since it could interfere during the reading of absorbance values by using UV spectrophotometer. The presence of precipitate causes spectral interferences due to the colloidal particles spread in the solution [27, 28]. Therefore, in order to have an accurate absorbance reading, appropriate dilutions of the samples are necessarily required to make sure their concentrations are below $7.5 \mathrm{ppm}$ before the addition of the two reagents (barium chloride and iodine) into the samples to avoid precipitation from occurs.

Table 5. Equation of standard curve and $\mathrm{R}^{2}$ values for Sabde et al. method and newly modified method

\begin{tabular}{lcccc}
\hline \multirow{2}{*}{$\begin{array}{l}\text { PEG MW } \\
\text { (g/mol) }\end{array}$} & \multicolumn{2}{c}{ Sabde et al. Method } & \multicolumn{2}{c}{ Newly Modified Method } \\
\cline { 2 - 5 } & Linear Equation & $\mathbf{R}^{2}$ Value & Linear Equation & $\mathbf{R}^{2}$ value \\
\hline PEG600 & $\mathrm{y}=0.0546 \mathrm{x}+0.135$ & 0.9431 & $\mathrm{y}=0.0043 \mathrm{x}+0.578$ & 0.9959 \\
PEG1000 & $\mathrm{y}=0.0506 \mathrm{x}+0.135$ & 0.9319 & $\mathrm{y}=0.0085 \mathrm{x}+0.578$ & 0.9991 \\
PEG3000 & $\mathrm{y}=0.0588 \mathrm{x}+0.135$ & 0.9779 & $\mathrm{y}=0.0094 \mathrm{x}+0.578$ & 0.9977 \\
PEG6000 & $\mathrm{y}=0.0551 \mathrm{x}+0.135$ & 0.9955 & $\mathrm{y}=0.0074 \mathrm{x}+0.578$ & 0.9952 \\
PEG10000 & $\mathrm{y}=0.0517 \mathrm{x}+0.135$ & 0.9863 & $\mathrm{y}=0.0064 \mathrm{x}+0.578$ & 0.9954 \\
PEG20000 & $\mathrm{y}=0.0484 \mathrm{x}+0.135$ & 0.9982 & $\mathrm{y}=0.0053 \mathrm{x}+0.578$ & 0.9937 \\
\hline
\end{tabular}

Based on the results shown in Figure 2(b) and Table 5, the newly modified method gave linear relationship from 0 to $150 \mathrm{ppm}$ for PEG600 to PEG20000 with $\mathrm{R}^{2}$ values nearly 1 . Please note that this newly modified method is solely depended on complex formation between PEG and iodine only. The reaction is called halogenation where hydroxyl group in PEG will be substituted by iodide ion [24]. In this reaction, there is no precipitation produced and observed since there is no involvement of metal ions like barium ion that can form precipitate. The main advantage of this method is that there is no precipitate formed even at concentration up to $400 \mathrm{ppm}$. Furthermore, this newly modified method only used $0.3 \mathrm{~mL}$ of the collected samples, is tenth times much lower than Sabde et al. method which required as much as $4 \mathrm{~mL}$ samples during PEGs detection. There are membranes which requires 1 hour only to collect $1 \mathrm{~mL}$ permeate, thus this newly modified method could reduce the time required for permeate collection.

Since there was no reaction mechanism so far reported for both methods, the mechanisms are proposed in Figure 3 based on the findings obtained in this work. Both methods use Lewis acid-Lewis base reaction as basis, where halogen ( $\mathrm{Cl}$ or/and I) acts as the electrophilic species (Lewis acid) while electron-rich organic compound (PEG) as the nucleophilic species (Lewis base) [24]. As for the former method by Sabde et al. [16], the mechanism is as shown in Figure 3 (Reaction 1). Firstly, hydroxyl group $(\mathrm{OH})$ at both end of PEG is substituted with chloride ion $\left(\mathrm{Cl}^{-}\right)$(upon addition of barium chloride solution into PEG solution), left barium ion $\left(\mathrm{Ba}^{2+}\right)$ on its own. $\mathrm{Ba}^{2+}$ thereafter forms ionic bonding with iodide ion $\left(\mathrm{I}^{-}\right)$after the addition of iodine solution into the mixture. This bonding tends to precipitate at concentration $10 \mathrm{ppm}$. In contrast, hydroxyl group of PEG is substituted directly by $\mathrm{I}^{-}$ upon the addition of iodine solution into PEG solution as illustrated in Figure 3 (Reaction 2) for the newly modified method. No precipitation is produced in Reaction 2 as found in Reaction 1. 


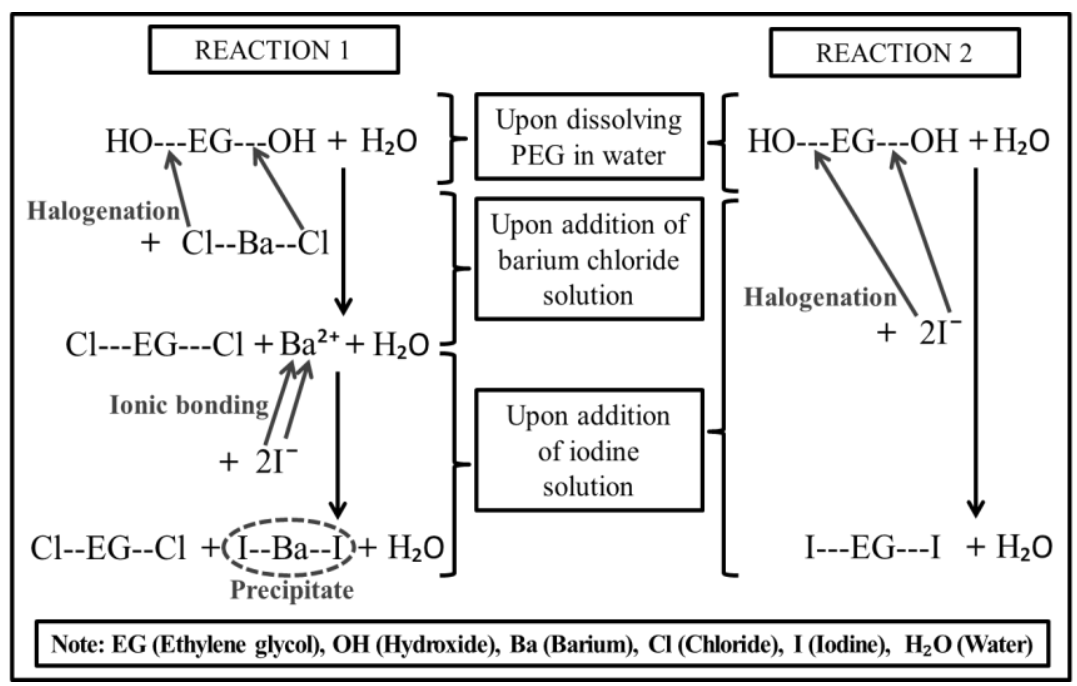

Figure 3. Proposed reaction mechanism for MWCO determination methods

\section{Methods accuracy test}

Three types of PEG with different MW were used for this accuracy test which is PEG with lowest (PEG600), middle (PEG6000) and highest (PEG20000) MW. A set of samples solution were prepared from these three PEGs to examine the accuracy of both compared methods. The test was repeated for three times to determine the standard deviation and further minimizing the error.

From the results showed in Table 6, both methods gave accurate values (calculated and actual) for the concentration of the samples solution. There was no dilution needed during the accuracy test for the newly modified method. However, the former method required some dilutions to be done especially for PEG6000 and PEG20000 (refer Table 6). The concentrations of the solutions were 16.0 and $26.7 \mathrm{ppm}$, respectively. At this concentration, precipitation tends to occur since their concentrations are above $10 \mathrm{ppm}$. Therefore, dilution must be conducted during using the former method to determine the concentration of the solutions. Luckily, the dilution work that has been conducted to eliminate precipitation is easily done since their final concentration is known. However, if this former method is applied for quantifying the MWCO of a membrane from pressure filtration, it will be very difficult to identify the dilution factor to bring the solution's concentration at below $10 \mathrm{ppm}$ since the permeate concentration is unknown. Thus, this test can be showed as a proof that the newly modified method is easier, more reliable and accurate to be used in determining MWCO of various filtration membranes specifically for NF and UF than the former method reported by Sabde et al. [16].

\section{Commercial membranes solute filtration test}

Commercial NF and UF membranes were used in solute filtration test for the MWCO study. NF and NF270 membranes were kindly donated by Dow Chemical Company. TF(GM) membranes and NF2, PES3, PES10, and PS20 were purchased from GE Osmonics and Amfor Inc. respectively (refer Table 2 for details). MWCO of all membranes were determined by using PEG with MW ranges from 600 to 20,000 g/mol. The solute MW ranges was divided into two categories: (i) NF range for MWCO below 2,000 g/mol, and (ii) UF range for MWCO above 2,000 $\mathrm{g} / \mathrm{mol}$. Table 7 and Figure 4 show the results of the fluxes and MWCO for all the NF and UF membranes tested by both methods. It was found that the fluxes for the membranes in water were higher than in the PEG solutions, as expected. This is because the solutes in the solution hinder the permeation of water thus reducing the flux. The PEGs used for the flux in PEGs are from PEG600 to PEG20000. This flux value was averaged out from the flux obtained at each PEG solutions used. The higher the MW of PEG used, the lower the flux recorded. 
Table 6. Comparison between calculated and actual concentration of unknown samples

\begin{tabular}{lcccccc}
\hline \multirow{2}{*}{ PEG MW (g/mol) } & \multicolumn{3}{c}{ Sabde et al. Method } & \multicolumn{3}{c}{ Newly Modified Method } \\
\cline { 2 - 7 } & $\mathbf{6 0 0}$ & $\mathbf{6 0 0 0}$ & $\mathbf{2 0 0 0 0}$ & $\mathbf{6 0 0}$ & $\mathbf{6 0 0 0}$ & $\mathbf{2 0 0 0 0}$ \\
\hline Dilution factor & No & 0.25 & 0.25 & No & No & No \\
Absorbance value & & & & & & \\
Run 1 & 0.427 & 0.362 & 0.469 & 0.601 & 0.697 & 0.721 \\
Run 2 & 0.427 & 0.361 & 0.466 & 0.601 & 0.697 & 0.721 \\
Run 3 & 0.426 & 0.362 & 0.464 & 0.601 & 0.696 & 0.721 \\
Values by standard curve (ppm) & & & & & & \\
Run 1 & 5.3 & 16.5 & 27.6 & 5.3 & 16.0 & 26.7 \\
Run 2 & 5.3 & 16.4 & 27.4 & 5.3 & 16.0 & 26.7 \\
Run 3 & 5.3 & 16.5 & 27.2 & 5.3 & 16.0 & 26.7 \\
Values by calculation (ppm) & 5.3 & 16.0 & 26.7 & 5.3 & 16.0 & 26.7 \\
Standard deviation & \pm 0 & \pm 0.058 & \pm 0.2 & \pm 0 & \pm 0 & \pm 0 \\
\hline
\end{tabular}

Table 7. Membrane separation properties (flux and MWCO) of the different commercial membranes obtained from dead-end filtration test

\begin{tabular}{|c|c|c|c|c|c|c|c|}
\hline \multirow{2}{*}{ Membrane } & \multicolumn{2}{|c|}{ Pure Water PEGs Flux } & \multicolumn{2}{|c|}{ Sabde et al. Method } & \multicolumn{2}{|c|}{ Newly Modified Method } & \multirow{2}{*}{$\begin{array}{c}\text { Nominal MWCO } \\
\text { by Manufacturer } \\
(\mathrm{g} / \mathrm{mol})\end{array}$} \\
\hline & $\underset{\left(\mathbf{L} / \mathbf{m}^{2} . \mathbf{h}\right)}{\text { Flux }}$ & $\left(\mathbf{L} / \mathbf{m}^{2} . h\right)$ & MWCO & \% Error & MWCO & \% Error & \\
\hline $\mathrm{NF}^{\mathrm{TM}}$ & 175.2 & $163.7 \pm 2.95$ & 550 & +83.3 & 550 & +83.3 & $200-300$ \\
\hline NF2 & 174.8 & $109.6 \pm 1.16$ & 500 & +25.0 & 500 & +25.0 & $200-400$ \\
\hline NF270 & 389.2 & $194.3 \pm 4.92$ & 530 & +32.5 & 530 & +32.5 & 400 \\
\hline PES3 & 175 & $164.4 \pm 2.45$ & 3250 & +8.3 & 2980 & -0.7 & 3000 \\
\hline $\mathrm{TF}(\mathrm{GM})$ & 258 & $244.9 \pm 1.01$ & 4600 & +15.0 & 3990 & -0.3 & 4000 \\
\hline PES10 & 150 & $129.3 \pm 0.65$ & 2600 & -74.0 & 10000 & 0 & 10000 \\
\hline PS20 & 280 & $205.5 \pm 0.78$ & 8600 & -57.0 & 19850 & -0.8 & 20000 \\
\hline
\end{tabular}

In terms of the MWCO values, the newly modified method gave the most accurate values for the UF membranes as given by the manufacturers. For example, PES10 has the same value as given while PES3, TG(GM) and PS20 values were found to be $<1 \%$ difference than the given values indicating the accuracy of the newly modified method. However, the MWCO values of the UF membranes determined by Sabde et al. method was different from the nominal MWCO given by the manufacturer. There are up to $74 \%$ difference in the calculated values. Of all the tested UF membranes, PES10 and PS20 have the farthest difference compared to others. This difference might be due to the dilution factor, which is required during the determination. The bigger the concentration of the PEG, the tendency for precipitation to occur is higher. Therefore, the detection of the absorbance values in spectrophotometer became imprecise. 
(a)

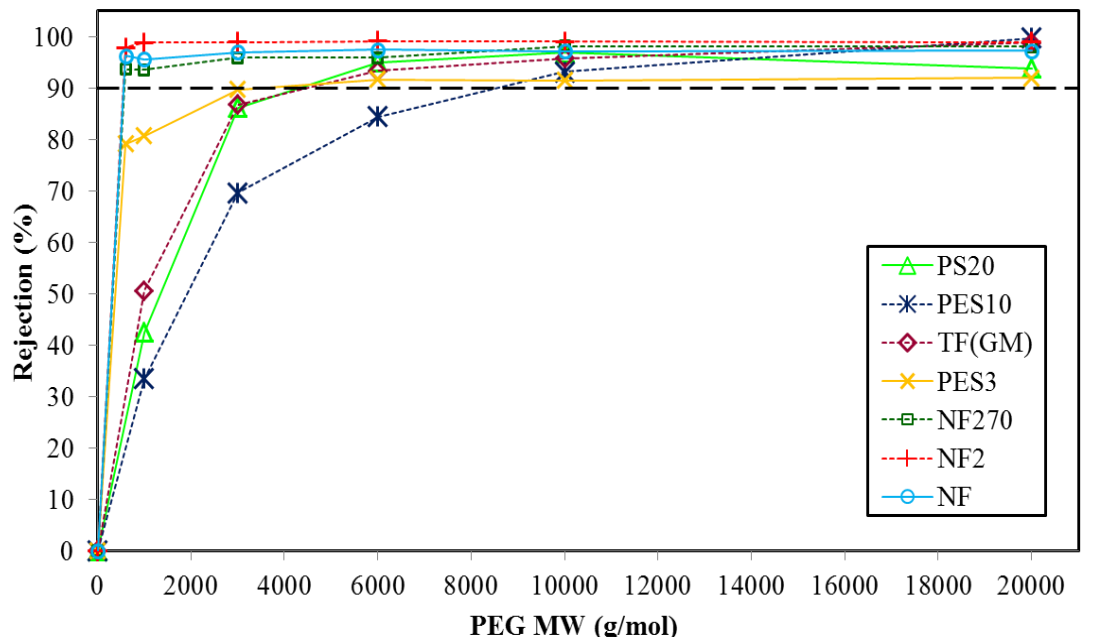

(b)

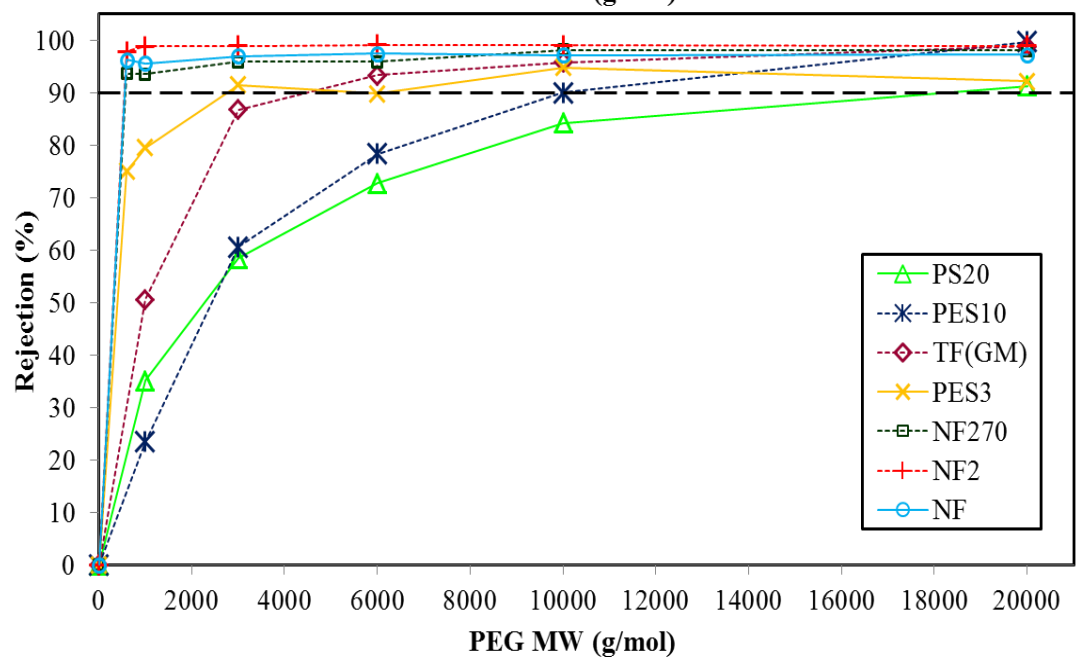

Figure 4. MWCO curve for commercial membranes using the PEG as solute filtration following both methods, (a) Sabde et al. and (b) newly modified method

Meanwhile the difference in MWCO values for NF membranes (for both method) were unavoided due to the lowest MW of PEG is $600 \mathrm{~g} / \mathrm{mol}$ only while the membranes' MWCO were given in the range of 200 to $400 \mathrm{~g} / \mathrm{mol}$. NF270 and NF2 have the closest MWCO values while NF ${ }^{\mathrm{TM}}$ has the farthest values. Since the current method could not apply PEG 200 and 400 yet, optimization of the method is still on going to include this PEG in the range. NF membrane's MWCO at $500<\mathrm{MWCO}<2000 \mathrm{~g} / \mathrm{mol}$ is expected to give accurate values as found in UF ranges. Similar research work was reported to confirm the developed MWCO method [12, 29, 30]. The difference in the MWCO of the membrane in comparison to the values provided by the manufacturers was discussed in details. For example, [12] have found a single run of pressure filtration with a mixture of PEGs in aqueous solution to determine MWCO of membranes. However, the method used to determine the MWCO have utilized a high-end equipment of HPLC coupled with ELSD detector though using PEGs as the solutes. Other work has also used gas chromatography (GC) with specific column to determine the styrene derivatives [10], alkanes detected in HPLC [30]. Based on this comparison study, the newly modified method is confirmed can accurately determine the MWCO in the range of 500 to $20,000 \mathrm{~g} / \mathrm{mol}$, which indicates the reliability of this method to substitute the method currently referred to [16]. 


\section{Conclusion}

A simple yet sensitive MWCO detection method was modified and developed from the commonly referred method in order to accurately determine PEG concentration in solute retention. The accuracy of this method is confirmed based on the filtration test using a range of commercial membranes. The MWCO values were found to be closed to the values given by the manufacturer. Since the accuracy of this method was verified and confirmed, this newly modified method could be used for determining membranes MWCO of either commercial or synthesized ones. High concentration of PEGs solution could be detected without the need for dilution since appropriate single reagent was used, thus no precipitation is presence as supported by the proposed reaction mechanism. This method can accurately determine the membrane MWCO $(\mathrm{g} / \mathrm{mol})$ in the range of $500<\mathrm{MWCO}<20,000$ as confirmed in this work.

\section{Acknowledgment}

The authors would like to acknowledge the financial support of the Fundamental Research Grant Scheme (FRGS/2/2013/TK05/UKM/02/4), GUP-2016-086 (UKM), Department of Chemical and Process Engineering, Universiti Kebangsaan Malaysia and MyMaster by MOSTI for the MSc scholarship.

\section{References}

1. Alam, J., Dass, L. A., Alhoshan, M. S., Mostafa Ghasemi and Mohammad, A. W. (2011). Development of polyaniline-modified polysulfone nanocomposite membrane. Applied Water Science, 2(1): 37 - 46.

2. Zhao, Q., Quanfu, A. F., Ji, Y., Qian, J. and Gao, C. (2011). Polyelectrolyte complex membranes for pervaporation, nanofiltration and fuel cell applications. Journal of Membrane Science, 379(1-2): 19 - 45.

3. Prafulla, G. B., Sapkal, V. S. and Sapkal, R. S. (2012). The optimization and production polyethersulfone ultrafiltration flat sheet membranes using lithium chloride as additives. International Journal of Engineering Research and Development 1(12): 65 - 68.

4. Uludag, H., Paul, D.V. and Patrick, A. T. (2000). Technology of mammalian cell encapsulation. Advanced Drug Delivery Reviews, 42: 29 - 64.

5. Derakhsheshpoor, R., Homayoonfal, M., Akbari, A. and Mehrnia, M. R. (2013). Amoxicillin separation from pharmaceutical wastewater by high permeability polysulfone nanofiltration membrane. Journal of Environmental Health Science and Engineering, 11(1): 9 - 19.

6. Idris, A. and Zain, N. M. (2006). Effect of heat treatment on the performance and structural details of polyethersulfone ultrafiltration membranes. Jurnal Teknologi, 44: 27 - 40.

7. Kim, K. J., Fanen, A. G., Ben Aimb, R., Liub, M. G., Jonsson, G., Tessaro, C. I. C., Broekd, A. P. and Bargemand, D. (1994). A comparative study of techniques used for porous membrane characterization: Pore characterization. Journal of Membrane Science, 87: 35 - 46.

8. Nakao, S.-I. (1994). Review: Determination of pore size distribution 3. Filtration membranes. Journal of Membrane Science, 96: 131 - 165.

9. Changzsheng, Z., Xuesong, Z. and Yilun, Y. (2000). Determination of pore size and pore size distribution on the surface of hollow-fiber filtration membranes: A review of methods. Desalination, 129: 107 - 123.

10. Kang, E., Lee, Y., Chon, K. and Cho, J. (2014). Effects of hydrodynamic conditions (diffusion vs. convection) and solution chemistry on effective molecular weight cut-off of negatively charged nanofiltration membranes. Desalination, 352: 136 - 141.

11. Hassan, A. R. and Ismail, A. F. (2004). Characterization of nanofiltration membranes by the solute transport method: some practical aspects in determining of mean pore size and pore size distributions. Regional Symposium on Membrane Science and Technology. Puteri Pan Pacific Hotel, Johor Bharu, Malaysia: pp. 1 - 13.

12. Rohani, R., Hyland, M. and Patterson, D. (2011). A refined one-filtration method for aqueous based nanofiltration and ultrafiltration membrane molecular weight cut-off determination using polyethylene glycols. Journal of Membrane Science, 382(1-2): 278 - 290.

13. Felo, M. and DeFrees, S. (2012). Nucleotide Sugar Purification using membranes in google patent. Novo Nordisk A/S, Bagsvaerd (DK): United States. 27.

14. Cheng, T. L., Chuang, K. H., Chen, B. M. and Roffler, S. R. (2012). Analytical measurement of PEGylated molecules. Bioconjugate Chemistry, 23(5): 881 - 899.

15. Kolate, A., Baradia, D., Patil, S., Vhora, I., Kore, G. and Misra, A. (2014). PEG - A versatile conjugating ligand for drugs and drug delivery systems. Journal of Control Release, 192: 67 - 81. 
16. Sabde, A. D., Trivedi, M. K., Ramachandhran, V., Hanra, M. S. and Misra, B. M. (1997). Casting and characterization of cellulose acetate butyrate based UF membranes. Desalination, 114: 223 - 232.

17. Idris, A., Mat Zain, N. and Noordin, M. Y. (2007). Synthesis, characterization and performance of asymmetric polyethersulfone (PES) ultrafiltration membranes with polyethylene glycol of different molecular weights as additives. Desalination, 207(1-3): 324 - 339.

18. Padaki, M., Isloor, A. M. and Wanichapichart, P. (2011). Polysulfone/N-phthaloylchitosan novel composite membranes for salt rejection application. Desalination, 279(1-3): 409 - 414.

19. Prafulla, G. B., Sapkal, R. S. and Sapkal, V. S. (2008). Influence of ethanol concentration on the performance of polyethersulfone ultrafiltration membranes. International Journal of ChemTech Research, 4(4): 1518 - 1521.

20. Shirley, J., Mandale, S. and Kochkodan, V. (2014). Influence of solute concentration and dipole moment on the rejection of uncharged molecules with nanofiltration. Desalination, 344: 116 - 122.

21. Fella, C. (2008). Dynamic and effective gene vectors via ph-sensitive peg-shielding. Thesis Doctor of Philosophy. Faculty of Chemistry and Pharmacy, Ludwig Maximilian University of Munich, Miltenberg.

22. Christopher, B., Drewes, J. E., Pei, X. and Gary, A. (2004). Factors affecting the rejection of organic solutes during NF/RO treatment - A literature review. Water Research, 38: 2795 - 2809

23. Bernadisiute, U., Antanelis, T., Vareikis, A. and Makuska, R. (2008). Iodination of poly(ethylene glycol) by a mixture of triphenyl phosphite and iodomethane. Chemija, 19(2): 43 - 49.

24. Moulay, S. (2013). Molecular iodine/polymer complexes. Journal of Polymer Engineering, 33(5): 389 - 443.

25. Shaffer, C. B. and Critchfield, F. H. (1947). Solid polyethylene glycols (carbowax compounds) quantitative determination in biological materials. Analytical Chemistry, 19(1): 32 - 35.

26. Barker, T. H., Klinger, M. M., Feldman, D. S., Fuller, G. M. and Hagood, J. S. (2001). Spectrophotometric analysis for determining the average number of poly(ethylene) glycol molecules on PEGylated proteins utilizing a protein digestion step. Analytical Biochemistry, 290(2): 382 - 385.

27. Lozzi, I., Pucci, A., Pantani, O. L., D'Acqui, L. P. and Calamai, L. (2008). Interferences of suspended clay fraction in protein quantitation by several determination methods. Analytical Biochemistry, 376: 108 - 114.

28. Wuelfing, W. P., Kosuda, K., Templeton, A. C., Harman, A., Mowery, M. D. and Reed, R. A. (2006). Polysorbate $80 \mathrm{UV} / \mathrm{vis}$ spectral and chromatographic characteristics - defining boundary conditions for use of the surfactant in dissolution analysis. Journal of Pharmaceutical and Biomedical Analysis, 41: 774 - 782.

29. Tam, C. M. and Tremblay, A. Y. (1991). Membrane pore characterization-comparison between single and multicomponent solute probe techniques. Journal of Membrane Science, 57: 271 - 287.

30. Rissler, K. (1996). High-performance liquid chromatography and detection of polyethers and their mono(carboxy)alkyl and -arylalkyl substituted derivatives. Journal of Chromatography A, 742: 1 - 54. 